\title{
The Legal Status of Certified Land Ownership of People Inhabiting around Limboto Lake
}

\author{
Mohamad Taufiq Zulfikar Sarson \\ Faculty of Law, Universitas Negeri Gorontalo, Indonesia \\ *Corresponding Author: M.T.Z Sarson, email: mtaufiqzulfikars@gmail.com
}

Abstract: The raised ground (aanslibing) is land directly controlled by the State, and therefore every person who will control the land arise (aanslibing) must obtain prior permission from the government. The aim of this research was to determine and understand the process of issuance of ownership land certification around Limboto Lake after the silting up and determine the legal protection of owners certified land after the revitalization of the lake. The research was carried out at plains of Limboto Lake at two Sub-Districts: Hutuo and Hunggaluwa, District of Gorontalo, Province of Gorontalo. Data collection employed interview and documentation techniques. The result of research showed that the issuance procces of certified land ownership around Limboto Lake was based on The Goverment Regulation No. 241997 concerning land registration. The regulation includes one of which was land with a hundred meters (100) distance from the lake border, land without certification at all, the land which is not under dispute, the land which is not under the bank fiduciary, the land which is under the authority of community proven by document legalizing the authority signed by the village head. For the ownership of land deposit, permit from the regional goverment is required. However, the National Land Body does no longer issue land ownership certification with reference to circulation letter of the Governor of Gorontalo Province. Legal protection for the holders of certified land after the revitalization activities may be attempted by the issuance of regional regulation draf that concerns the Provincial Space Management Planning of Strategic Areas of the Limboto Lake. However, legal protection for the certificates issued previously has not been available due to the onggoing procces of discussion of the Regional the Regulation Draft.

Keywords: Land Ownership; Certification; Legal Protection; Limboto Lake

\section{How to cite:}

Sarson, M.T.Z. (2020). The Legal Status of Certified Land Ownership of People Inhabiting around Limboto Lake. Indonesian Journal of Advocacy and Legal Services, 2(1), 5-18. DOI: 10.15294/ijals.v2i1.36095 


\section{A. Introduction}

Soil is defined as the body of the transformation of minerals and organic matter on the surface of the earth under the influence of various environmental factors. Juridical provisions related to the existence of Land in Law Number 5 of 1960 concerning Basic Regulations on Agrarian Principles (hereinafter referred to as UUPA). The control and arrangement by the State is directed to realize social justice for all Indonesian people. Therefore, clarity about the status of land ownership is very important to be studied further. ${ }^{1}$

After the issuance of Government Regulation Number 16 of 2004 concerning Land Stewardship and the enactment of Law Number 9 of 2015 concerning Regional Government has brought a breath of fresh air for regions to make and manage their own policies in terms of regional regulation. ${ }^{2}$ At the Lake Indonesia 1st National Conference on August 13 to 15 2009, 15 priority lakes have been set up that will be handled together in an integrated, environmentally friendly and sustainable manner in the period 2010-2014. Determination of Lake priority is based on Lake damage, Lake utilization, commitment of Local Governments and communities in Lake management, strategic functions for national interests, biodiversity, and the level of disaster risk. The 15 lakes are Lake Toba, Maninjau, Singkarak, Kerinci, Tondano, Limboto, Poso, Tempe, Matano, Mahakam, Sentarum, Sentani, Batur, Lake Swamp, and Rawapening. One of the 15 priority lakes is Lake Limboto. ${ }^{3}$

One of the natural resource assets currently owned by Gorontalo is Lake Limboto. Lake Limboto which is one of the icons of natural resources owned by Gorontalo Province which is administratively located in two regions, namely $\pm 30 \%$ in the Gorontalo City area and $\pm 70 \%$ in the Gorontalo District region which is capable of reaching up to 7 Districts, 6 Districts in Gorontalo Regency, namely Limboto District, West Limboto District, Telaga

1 Wirardi G, Seluk Beluk Masalah Agraria, Reforma Agraria, dan Penelitian Agraria, STPN-Press, Yogyakarta, 2009, pp. 56-58.

2 Junus N dan Bakung D.A, Status Hukum Penguasaan tanah Bantaran Danau Limboto Di Provinsi Gorontalo, Fakultas Ilmu Sosial, Universitas Negeri Gorontalo, Gorontalo, 2012, pp. 53-56; Junus, N. (2012). Status Hukum Penguasaan tanah Bantaran Danau Limboto Di Provinsi Gorontalo. Jurnal Pelangi Ilmu, 5(1), 1-19. http://ejurnal.ung.ac.id/index.php/JPI/article/view/895/835; Christopel Paino, Sengkarut Lahan dan Revitalisasi Danau Limboto (bagian - 1), 25 April 2016, retrieved from https://www.mongabay.co.id/2016/04/25/sengkarut-lahan-dan-revitalisasi-danaulimboto-bagian-1/

3 Bali Agreement, 1st Indonesia National Lake Conference Bali, August 13-15, 2009. 
District, Tilango District, Telaga Biru District, Batudaa District and 1 District in Gorontalo City, namely Kota Barat District. ${ }^{4}$

Based on data from the results of a survey of the Agency for the Development of Environmental Impact Management and Control (BALITBANGPEDALDA, 2016, BALITBANGPEDALDA. M with an area of $\pm 9000 \mathrm{Ha}$, and in 2003 until now the depth is $\pm 2 \mathrm{~m}$ with an area of \pm 2900 Ha. So that within a span of 81 years Lake Limboto's area was reduced by 6,100 ha (67.77\%). If calculated annually the Lake's depreciation rate reaches 75.89 ha. and predicted in 2025 Lake Limboto will turn into land. This indicates the level of silting experienced by Lake Limboto will leave a vast expanse of land or land.

Lake Limboto area which is an open area (open access) with a variety of potential has experienced a process of exploitation continuously even tends to be excessive and does not pay attention to aspects of its preservation. Lake Limboto's condition is currently in a critical situation and is very worrying. As a result of the silting of Lake Limboto, most of the areas that used to be turned into lake settlements or converted into agricultural businesses. Other things that are a problem around Lake Limboto are the uncontrolled growth of water hyacinth, fishing using poisons (Potassium Clorida), fish bombs and large-scale fishing gear that have resulted in decreased genetic diversity of fish and other aquatic biota, and decreased water quality Lake. ${ }^{5}$

By law the national land, arising land (aanslibing) is land that is controlled directly by the State, therefore everyone who will control the arising land (aanslibing) must obtain prior permission from the government authority in charge for that, namely the National Land Agency. Harsono $(2008)^{6}$, referred to as aanslibing is the growth of land on the edge of a river, lake or sea, land that grows is considered to be the property of people who own bordering land, because usually the growth is more or less due to their

4 Mopangga M.S, Peran Pemerintah Daerah Kabupaten Gorontalo Dalam Meminimalisir Konversi Sempadan Danau Limboto Menjadi Pemukiman Bebas, Fakultas Hukum Universitas Negeri Gorontalo, Gorontalo, 2014, pp. 35-37.

5 Azizi, A., Krismono, K., \& Sarnita, A. S. (2017). Kajian Sosial Ekonomi Nelayan di Danau Limboto, Sulawesi Utara. Jurnal Penelitian Perikanan Indonesia, 1(4), 49-60. http://dx.doi.org/10.15578/jppi.1.4.1995.49-60; Umar, I. (2018). Analisis Perubahan Penggunaan Lahan Sekitar Danau Limboto Di Kabupaten Gorontalo: Tahun 19912017 (Doctoral Dissertation, Universitas Gadjah Mada); Nusantari, E. (2012). Kerusakan Danau Limboto dan Upaya Konservasi Melalui Pemberdayaan Masyarakat dan Peran Perguruan Tinggi. Jurnal Pendidikan Biologi, 1(2).

6 Harsono B, Hukum Agraria Indonesia. Jakarta, Djambatan, 2008, pp. 67-69; Khairizal Dermawan Lahabu, Studi Tentang Pendudukan Terhadap Tanah Timbul (Aanslibbing) Di Kawasan Tepian Danau Limboto Provinsi Gorontalo, Student Journal, 2025 (2016), pp. 1-11. http://hukum.studentjournal.ub.ac.id/index.php/hukum/article/view/2025 
business. ${ }^{7}$ Automatically the occurrence of such Property Rights is also through a time-consuming process of growth.

In 2014 the Gorontalo provincial government launched the Lake Limboto revitalization program through a Regional Regulation Draft (RANPERDA) which intends to restore Lake Limboto's function as before, the government held Lake Limboto dredging both upstream and downstream. Automatically, communities around Lake Limboto along the Lake Limboto revitalization program will feel the impact of the Lake Limboto revitalization program, people who live around Lake Limboto, both those who have land titles or those who do not have land titles, will be moved or relocated. This relocation or relocation process requires a long socialization because in reality it is not easy to move or relocate the community around the limboto lake banks. People who already have land title certificates feel they have the right to live and settle on the banks of Lake Limboto. This study aims to find out and understand how the process of issuing certificates of ownership of land by communities around the Lake Limboto area near post-silting as well as legal protection for people holding post-siltation certificate of ownership. ${ }^{8}$

\section{B. Method}

\section{Research Location}

This research was conducted in Gorontalo Regency, Gorontalo Province more precisely around the Bantoto Lake area, with the consideration that the object of research was in the area of Limboto District, Hutuo Village and Hunggaluwa Village.

\section{Research Type}

This research is a combination of normative and empirical legal research. From the normative aspect, the authors conducted a prescriptive study, using a statutory approach, by examining the laws and regulations that are relevant to the legal issues under study. ${ }^{9}$

7 BALITBANGPEDALDA, Data Badan Penelitian Pengembangan Dan Pengendalian Dampak Lingkungan Hidup Provinsi Gorontalo, Gorontalo, 2016.

8 Gobel, Erwin Zubair, and Yosef P. Koton. Pengelolaan Danau Limboto dalam Perspektif Implementasi Kebijakan Publik, Jakarta, Deepublish, 2017, pp. 67-69; Kamaru, K., \& Sudjito, S. H. (2008). Tinjauan Yuridis tentang kepemilikan Tanah Bantaran (Lidah Tanah) pada Danau Limboto Propinsi Gorontalo (Doctoral Dissertation, Universitas Gadjah Mada).

9 Marzuki P.M, Penelitian Hukum Edisi Revisi, Surabaya, Kencana Prenada Media, Jakarta, 2013, pp. 65-66; Arifin, R., Waspiah, W., \& Latifiani, D., Penulisan Karya Ilmiah untuk Mahasiswa Hukum, Semarang, BPFH UNNES, 2019, pp. 77-79. 


\section{Population and Sample}

The population of this research is all parties related to this research. The parties in question are the people who live around the Lake Limboto area that has both ownership certificates and those who do not have certificates, as well as the Gorontalo Provincial Government, namely: Head of the Office of Agrarian Affairs and Spatial Planning / National Land Agency of Gorontalo Regency Gorontalo Province and Gorontalo Province Regional Planning and Development Agency (BAPEDA) and Gorontalo District Government.

The sample in this study was selected by purposive sampling. The samples in this study are: 1) People who live around the banks of Lake Limboto who have certificates (5 people), who do not have certificates (5 people). 2) Newcomers (5 people), native Bantaran Danau (5 people). 3) Gorontalo District National Land Agency (2 people). 4) Gorontalo Province Regional Planning and Development Agency (2 people). 5) Gorontalo District Government (2 people).

\section{Data Collection Method}

The data collection used in this study are as follows: 1) Interview with visiting respondents by conducting direct questioning, type of regular and structured questions; 2) Documentation for collecting data related to this research.

\section{Data Analysis}

In accordance with the problems to be answered and the objectives to be achieved in this study, the data obtained will be analyzed descriptively qualitatively namely describing the data obtained from field research (primary data), tested the truth then linked and analyzed qualitatively with data obtained from library research (secondary) which is then followed by interpretations and conclusions so as to discuss the problem thoroughly and objectively ${ }^{10}$ (Sukanto, 2012).

\section{Result}

Lake Limboto is located in the central part of Gorontalo Province and is located between two regions namely Gorontalo Regency and Gorontalo City at Longitude coordinates 122056 '- 123001 East and Latitude 00 34' - 0036 " LU. Limboto Lake is administratively bordered by several sub-districts, including Limboto Sub-District, Batudaa, which is included in Gorontalo

10 Sukanto S., Pengantar Penelitian Hukum, UI Press, Jakarta, 2012, pp. 35-38 
Regency and Telaga District, Gorontalo City. The area of the lake is located in two regions, namely $\pm 30 \%$ of Gorontalo City area and $\pm 70 \%$ in Gorontalo Regency and covers 5 districts.

Lake Limboto is a lagoon that becomes the estuary of several rivers around the lake with an area of about 3,625 hectares, with an average depth of 2.5 meters. The source of water entering Limboto Lake is derived from rainwater and the flow of the Biyonga river which flows throughout the year to the north of Lake Limboto, also from other rivers as many as 23 rivers spread to the north, south and west of the lake (Table 1 ). Of the 23 rivers there are five major rivers namely Biyonga river, Meluopo river, Marisa river, Alopohu river, and Rintenga river and 18 tributaries that contribute to lake water volume. The only outlet for Lake Limboto is the Topodu river, which flows into Tomini Bay via the Bolango river.

The area of Lake Limboto's banks which are controlled by respondents covers an area of land between 1000 and $1999 \mathrm{~m}^{2}$, more than the total land area held by the respondent, the amount is as much 7 people or $35 \%$, land area between 2000 to $2999 \mathrm{~m}^{2}$ and 3000 to $3999 \mathrm{~m}^{2}$ each with 5 people or $25 \%$, land area between 4000 to $4999 \mathrm{~m}^{2}$ with 2 people or $10 \%$, and land area more than $5000 \mathrm{~m}^{2}$ of 1 person or $5 \% .^{11}$

The data shows the majority of respondents in the Bantaran Lake Limboto area are relatively broad. This is due to the fact that the land has been used as a dwelling place since the 1980s, where the form of control of the land since the 1980s took the form of hereditary physical control from her family but did not yet have a certificate of ownership, this physical control does not constitute control within the scope of law adat but only in the form of a unilateral possession in which the community sets the boundaries of the land of the dam, the forms of lake use are mostly in the form of agricultural land, plantations, or dwelling which is lived in for generations, many of these areas are cultivated by the community and do not yet have a boundary has been determined by the government so that the land area they have acquired is very broad, but at that time many did not yet have certificates from the government or other legal permits from the government.

The banks of the banks of the lake in Limboto are mostly controlled by respondents to be used as dwellings, plantations, and agriculture, although there are some of the respondents who use these residences for trading activities (household needs). For respondents, this lakebank land is used and

11 Umar, I., Marsoyo, A., \& Setiawan, B. (2019). Analisis Perubahan Penggunaan Lahan Sekitar Danau Limboto Di Kabupaten Gorontalo. Jurnal Tata Kota dan Daerah, 10(2), pp. 77-90. 
controlled because the riverbank is their place of life, this is because the respondent has no alternative housing other than the land in Lake Limboto.

Based on the results of an interview with one of the interviewees that they have tried to get another place to live, but they cannot afford to buy land elsewhere because the price is very expensive, and on the banks of the Lake Limboto they depend on their lives as farmers and fishermen as their alternative remains on the banks of the lake. This was emphasized by Sutarjo Pol Gorontalo, one of the community leaders in Hahano Village, Limboto District, Gorontalo District, interview on 16 October 2016, stated: a decent loss, while land in other areas (not landbanks), land in cities is already very expensive and we cannot afford it, so we better stay here.

This respondent's statement is only part of the complaints received, according to respondents who numbered 20 people an attempt to obtain another place to live has been carried out, but because they are unable to buy land elsewhere they remain alive and live on the banks of Lake Limboto. They also did not mind if they had to be moved (freed) from the land resulting from the silting of Lake Limboto, but the transfer must be to a better place (not on the banks of Lake Limboto) and obtain sufficient compensation to obtain a better place to live.

\section{Result}

In this study shows that the serious problem faced by Gorontalo District Government in an effort to handle the status of Lake Limboto's banks is the attitudes and perceptions of the people who do not provide a response to the explanation of the status of the banks. The government is difficult to make an inventory of residents who live on the banks of the Lake Limboto. This is due to the fact, that many residents have controlled the bantaran land for generations without permission from the local government or without reporting to local government officials.

Many residential buildings that are established by residents are generally permanent and semi-permanent, while temporary buildings are only used as a place to sell. The problem that is often faced by residents is about land boundaries, this problem often arises horizontal conflicts among the community about the boundaries of the land they control and conflicts between citizens in the use of land for agriculture, plantations, and shelter. These land boundaries were determined by themselves without the knowledge of the government by using wooden stakes, but these land boundaries will be lost due to flooding caused by the overflow of Lake Limboto in the rainy season and often revoked or moved by others. 
With the loss of land boundaries or wooden pegs it is often a problem where residents who object to the loss of the boundaries often make new boundaries, while other residents do not accept the removal of new peg boundaries because they feel their boundaries have been taken by others. This conflict has often happened only to the extent of arguing (arguing) among neighboring residents and usually if there is such a thing, the head of the RT, RW and the Head of the Village immediately summoned the residents who argued, held a meeting to avoid physical contact or up to a court shirt.

As a result of population growth and along with the development and development of Gorontalo District, the existence of residents on the banks of Lake Limboto has increased rapidly. Generally, residents choose to live on the banks of Lake Limboto because they are unable to find a place to live in other places due to low economic conditions, in addition to the reason they live on the banks of Lake Limboto will make it easier for them to obtain living facilities such as work as farmers, fishermen traders and other living facilities that are easy to get unlike in urban areas. Thus, it is clear that the existence of residents on the banks of Lake Limboto has existed since long ago, but due to the development and development and population growth is quite rapid in Gorontalo District, especially on the banks of Lake Limboto so that many residents around using the banks of the riverbank as an alternative place to live their families who until now still has become a very significant problem by Gorontalo District Government and Gorontalo Provincial Government.

Limboto Lake which is located in Gorontalo Regency based on its geographical and topographical location, the highest control is in the hands of the State. The concept of a controlling State according to Soemardjono $(1984)^{12}$, is a State that has the authority of all the people (nation) of Indonesia, is given the position as a Ruling Agency which is at the highest level of authority to regulate legal relations and legal actions regarding land, as recipients of power, then all state actions relating to policy making must be accountable to the community. ${ }^{13}$ In the case of granting a certificate of ownership by the state to the community it must be accountable and the designation must be clear, the community is given the right to obtain a

12 Soemardjono, Pengantar Penelitian Hukum, Universitas Indonesia, Jakarta, 1984, pp. 1517.

13 Ali A., Menguak Teori Hukum (Legal Theory) dan Teori Peradilan (Judicialprudence) Termasuk Undang-Undang (Legisprudence) Volume 1 Pemahaman Awal, Kencana Prenada Media Grup, Jakarta, 2010, pp. 23-27 
certificate that is in accordance with the procedures based on applicable laws and regulations. ${ }^{14}$

Most of the limboto lake banks have gained ownership of the land through the inheritance, so long ago or for generations the community controlled the lake bank land and passed on to their children and grandchildren, the second most is through buying and selling, so there are also many people who control the land through the land buying and selling, this buying is obtained from people who have previously controlled the land of the riverbank for a long time and is sold to people who have just lived on the banks of the lake, then most recently namely through cultivation, the community obtained the land of the riverbank through cultivation which finally by the government Gorontalo District is given a certificate to help people get a more decent life.

In the process of issuing certificates of ownership by the community there are many inhibiting factors so that the community and the National Land Agency are not easy to administer and issue certificates. The inhibiting factors including Community Psychological Factors whereis communities do not understand the existence of a meaningful difference between the presence of a certificate from their land or the absence of a certificate on their land. Even in the eyes of the public, the protection afforded by the State to holders of certificates is almost the same as those without certificates. The reality in the absence of more guarantees from the State weakens people's desire to register their land.

In addition, the factor of weakness of land registration rules is also one factor. Until now, there are still many people who do not know about the rules for land registration. Therefore, materially, land registration should be expected to accelerate the realization of the implementation of land registration in this country ${ }^{15}$. However, in fact the number of registered parcels of land is not much compared to unregistered lands. Because it can be said that there is no reality of legal protection for the regulation, even the contents of the regulation cannot be maintained to provide a tool for achieving the target of the realization of the certificate of land rights in Indonesia ${ }^{16}$. Similarly, the factor lacking understanding of the function and use of certificates. Communities generally do not understand the function and use

14 Akibu, Rifkah S. "Implementasi Kebijakan Pengelolaan Danau Limboto." Dialektika 2(1), 2017, pp. 178-188; Hasim, H, Perspektif Ekologi Politik Kebijakan Pengelolaan Danau Limboto. Publik (Jurnal Ilmu Administrasi), 7(1), 2018, pp. 44-52.

15 Pide A.S.M., Quo Vadis Pendaftaran Tanah, Pukap, Makassar, 2009, pp. 55-56.

16 Sutedi A, Pengakuan Hak Milik Atas Tanah Menurut Undang-Undang Pokok Agraria, Cipta Jaya, Jakarta, 2006, pp. 112-114. 
of certificates, this is because the community lacks accurate information about land registration.

For people who want to register their land, have complained beforehand, because they estimate that land registration requires a lot of costs. Yet if it is carried out in accordance with existing regulations, the land registration fee is relatively cheap. Besides having to meet the cost of the applicant determined by the land registration rules, there are also other costs for the order of the law that cannot be ignored, such as the BPHTB (Land and Building Acquisition Fee) law which requires it to be paid in the event of a transfer and acquisition of land rights. All costs are charged from the provisions of the land registration rules themselves which make people reluctant to register their land.

There are still many complaints from the community regarding the implementation of land registration. As a result of the implementation that is considered indecisive, vague, and convoluted. And even different interpretations occur in doing his work. Surely, if this arises, then surely people will no longer be motivated to register their land. The community feels hard, burdened and not necessarily there are many benefits that can be felt by the community from the land registration.

Negative publicity system that contains positive elements. With this negative system, opportunities for others to sue people who already have certificates are open, so there is doubt in the community to register their land because it does not guarantee the absolute certainty of their land rights. In a negative system, if the person as the subject of his name is already registered in the land book, his rights are still possible to be denied, as long as the objections provide sufficiently strong evidence. This negative system has the disadvantage that the government does not guarantee the truth of the contents of public registers held in the process of registration of rights.

\section{E. Conclusion}

The process of issuing certificates of ownership rights to land around Lake Limboto near the banks of Lake Limboto is almost the same as the process of issuing certificates of ownership rights over other land in accordance with Government Regulation No. 24 of 1997 concerning Land Registration, but the difference is in the process of issuing certificates of ownership of land over the surrounding banks Lake Limboto must comply with applicable regulations, i.e. land that can be issued certificates must be within 100 meters of the lake border area, land has no certificate at all, the land is not in dispute, the land is not a guarantee or collateral in the bank, the land must be physically 
controlled by the community and there must be a land certificate or proof of the acquisition of the community controlling the land which is minimally strengthened by the village head. In the process of issuing certificates of ownership of land by communities around the banks of Lake Limboto, the BPN should work together with the Gorontalo District government to determine the boundaries of Lake Limboto boundaries, the Government must clearly determine which lake border areas can be issued certificates and the BPN must more socializing about how the status of Lake Limboto's bank land and which banks can be issued with certificates so that there is no conflict between the government and the communities around the Lake Limboto riverbank.

\section{F. Acknowledgments}

Authors would like to express the thakfullness to Faculty of Law, Universitas Negeri Gorontalo, as well as to Gorontalo Province Government for supporting this research.

\section{G. Declaration of Conflicting Interests}

The authors state that there is no potential conflict of interest in the research, authorship, and/or publication of this article.

\section{H. Funding}

None

\section{References}

Akibu, R. S. (2017). Implementasi Kebijakan Pengelolaan Danau Limboto. Dialektika, 2(1), 178-188. https://doi.org/10.36636/dialektika.v2i1.241

Ali, A. (2010). Menguak Teori Hukum (Legal Theory) dan Teori Peradilan (Judicialprudence) Termasuk Undang-Undang (Legisprudence) Volume 1 Pemahaman Awal. Jakarta: Kencana Prenada Media Grup.

Arifin, R., Waspiah, W., \& Latifiani, D. (2019). Penulisan Karya Ilmiah untuk Mahasiswa Hukum. Semarang: BPFH UNNES.

Bali Agreement. (2009). 1st Indonesia National Lake Conference Bali, August 13-15, 2009. 
BALITBANGPEDALDA. (2016). Data Badan Penelitian Pengembangan Dan Pengendalian Dampak Lingkungan Hidup Provinsi Gorontalo, Gorontalo, Tahun 2016.

Gobel, E. Z., \& Koton, Y. P. (2017). Pengelolaan Danau Limboto dalam Perspektif Implementasi Kebijakan Publik. Jakarta: Deepublish.

Harsono, B. (2008). Hukum Agraria Indonesia. Jakarta: Djambatan

Hasim, H. (2018). Perspektif Ekologi Politik Kebijakan Pengelolaan Danau Limboto. Publik (Jurnal Ilmu Administrasi), 7(1), 44-52. http://dx.doi.org/10.31314/pjia.7.1.44-52.2018

Junus, N., \& Bakung, D.A. (2012). Status Hukum Penguasaan tanah Bantaran Danau Limboto Di Provinsi Gorontalo, Fakultas Ilmu Sosial, Universitas Negeri Gorontalo, Gorontalo.

Junus, N. (2012). Status Hukum Penguasaan tanah Bantaran Danau Limboto Di Provinsi Gorontalo. Jurnal Pelangi Ilmu, 5(1), 1-19. http://ejurnal.ung.ac.id/index.php/JPI/article/view/895/835

Kamaru, K., \& Sudjito, S. H. (2008). Tinjauan Yuridis tentang kepemilikan Tanah Bantaran (Lidah Tanah) pada Danau Limboto Propinsi Gorontalo (Doctoral Dissertation, Universitas Gadjah Mada).

Lahabu, K.D. (2016). Studi Tentang Pendudukan Terhadap Tanah Timbul (Aanslibbing) Di Kawasan Tepian Danau Limboto Provinsi Gorontalo. Student Journal, 2025 (Magister Ilmu Hukum dan Kenotariatan), pp. $1-21$.

http://hukum.studentjournal.ub.ac.id/index.php/hukum/article/view/2 025

Marzuki, P.M. (2013). Penelitian Hukum Edisi Revisi. Jakarta: Surya Kencana Prenada Media.

Mopangga, M.S. (2014). Peran Pemerintah Daerah Kabupaten Gorontalo Dalam Meminimalisir Konversi Sempadan Danau Limboto Menjadi Pemukiman Bebas, Fakultas Hukum Universitas Negeri Gorontalo, Gorontalo.

Nusantari, E. (2012). Kerusakan Danau Limboto dan Upaya Konservasi Melalui Pemberdayaan Masyarakat dan Peran Perguruan Tinggi. Jurnal Pendidikan Biologi, 1(2). http://journal.um.ac.id/index.php/jpb/article/view/3843

Paino, C. Sengkarut Lahan dan Revitalisasi Danau Limboto (bagian - 1), 25 April 2016, retrieved from https://www.mongabay.co.id/2016/04/25/sengkarut-lahan-danrevitalisasi-danau-limboto-bagian-1/

Pide A.S.M. (2009). Quo Vadis Pendaftaran Tanah. Makassar: Pukap. 
Soemardjono. (1984). Pengantar Penelitian Hukum. Jakarta: Universitas Indonesia.

Sukanto, S. (2012). Pengantar Penelitian Hukum. Jakarta: UI Press.

Sutedi, A. (2006), Pengakuan Hak Milik Atas Tanah Menurut UndangUndang Pokok Agraria. Jakarta: Cipta Jaya.

Umar, I., Marsoyo, A., \& Setiawan, B. (2019). Analisis Perubahan Penggunaan Lahan Sekitar Danau Limboto Di Kabupaten Gorontalo. Jurnal Tata Kota dan Daerah, 10(2), 77-90. http://dx.doi.org/10.21776/ub.takoda.2018.010.02.3

Umar, I. (2018). Analisis Perubahan Penggunaan Lahan Sekitar Danau Limboto Di Kabupaten Gorontalo: Tahun 1991-2017 (Doctoral Dissertation, Universitas Gadjah Mada).

Wirardi, G. (2009). Seluk Beluk Masalah Agraria, Reforma Agraria, dan Penelitian Agraria. Yogyakarta: STPN-Press. 


\title{
Quote
}

\section{The desire for carnal possession quickly cools, whereas the desire to own land never quits the heart of man.}

\author{
Gabriel Chevallier
}

Clochemerle Babylon

Copyrights (C) 2020 by Auhtor(s). This work is licensed under a Creative Commons Attribution-NonCommercial-ShareAlike 4.0 International License. All writings published in this journal are personal views of the authors and do not represent the views of this journal and the author's affiliated institutions. 